\title{
Islamic Principles in Marketing: An Overview of Islamic Marketing mix in Social-Media Campaign
}

\author{
Syafwendi Syafril $^{1 *}$, M. Fuad Hadziq ${ }^{2}$ \\ ${ }^{1}$ Academy of Islamic Studies, University of Malaya, Kuala Lumpur, Malaysia \\ ${ }^{2}$ Islamic Economics Department, Universitas Terbuka, Indonesia \\ *Corresponding author e-mail: syafwendi05@gmail.com
}

\begin{tabular}{l}
\hline Article Info \\
\hline Keywords: \\
Islamic marketing; \\
Social media; \\
Marketing mix; \\
Islamic market \\
\hline
\end{tabular}

DOI:

10.33830/elqish.v1i1.1568.2021

\begin{abstract}
The increasing number of internet users among Muslims worldwide has open opportunities for business players to develop Islamic marketing and get attention from them. Social media becomes a popular platform for the Muslim community to interact, communicate, and share regarding humanity, education, donation, and the Islamic lifestyle. This paper arranges to analyzes the Islamic marketing mix that must be existed in social media campaigns. The Islamic principles in marketing are the main key to determine whether businesses not only provide sharia-compliant products and services but also succeed in comminates it based on Islamic ethics and value. The library research was conducted in research methodology to review marketing theory and concept from an Islamic perspective. Findings. The analytical result shows that the integrated Islamic principles such as halalan tayyiban, antimonopoly, gharar, speculation, excessive action, manipulative sales tactic, etc., should be eliminated in the marketing mix in social media campaigns. All that aims to ensure marketing activities run properly according to Shariah principles.
\end{abstract}

\section{Introduction}

Nowadays, the advancement of entrepreneurship has provided the world's society with a plethora of options for meeting their needs and desires. To meet those demands, a variety of businesses have a wide range of products and services, including household items, automobiles, information technologies, smart devices, wellness services, snacks, and drinks. In each sector, many companies compete for the customer's heart. They use a variety of tactics to entice consumers to purchase goods or services. A marketing strategy is a tool for companies to gain consumer interest and recognition (Lee \& Youn, 2009).

Many firms and industries today are confronted with not only the world's shifting marketing direction toward marketing 4.0, but also the growing number of Muslim societies in numerous countries searching for halal products in commerce. Furthermore, the growing number of internet users among Muslim Millenials under the age of 30 presents significant opportunities for businesses to extend their delivery of products and services (Furber, 2017). They would eventually have to deal with the Islamic marketing concept.

The whole industry must be sharia-compliant in the Islamic marketing concept, which means all inputs, processes, and outputs must adhere to Islamic law (Alserhan, 2011). In two significant ways, Islamic marketing is distinct from traditional marketing. To begin with, Islamic marketing values are based on set and absolute Qur'anic ethics. Second, value maximization is a universal desire that has a positive and broader effect on humanity (habluminnanas) and the environment, rather than maximizing profits. 
Nowadays, marketing has shifted due to the development of technology and information. In a short period, the company will overwhelm its marketing campaign with the internet. Everyone can access content from anywhere and at any time by using the internet on their mobile device. Today, everyone can communicate easily with a hundred, thousand, or even million people with social media platforms just by clicking the button. With social networking sites, anybody can quickly connect with a hundred, thousand, or even a million people by simply pressing a mouse. As a networking forum, social media apps have evolved into corporate and marketing media that businesses, companies, and SMEs use to introduce their products and services or meet their target market segment. The most cost-effective way to reach potential buyers and retain existing ones is to use digital and social media (Temporal, 2011). Digital and social media marketing can address problems that businesses have previously faced, such as demography, venue, or consumer characteristics, by bringing them together through digital tools. Internet and social media are powerful tools for bringing a global and multicultural audience together in one piece.

The digital age is paying attention to the muslim universe as well because the Muslim population from all over the world is going online every day. They take a part of the new world and adopt it as a modern way of life. Muslims utilize the internet to exchange information about their lifestyles such as halal cuisine, fashion, halal tourism, education, or share topics about Muslim and Islamic faith, among other things. Recently, they use a variety of social media platforms such as Facebook, Twitter, Youtube, Whatsapp, and Instagram to perform those actions. This is a significant incentive and momentum for marketers to reach out to Muslim society and begin developing an Islamic marketing strategy using social media networks.

As an opened-source platform, social media is the place where anybody can post content freely without filtering it first including positive and negative content that leads to provocation, abusive information, or even sexual intention. This phenomenon has become the main issue of the implementation of Islamic marketing principles in social media platforms. Most of the business players consciously or unconsciously publish the un-appropriate content to attract their customer, for example in the fashion industry the model use a tight wardrobe and showing the curves of her body to display the beauty of the product. On the other hand, the captions that include along with particular content sometimes are excessive and lead customers or targeted market to do an impulse behavior in purchasing products and services which may lead to Tabzir. As an attempt to address this particular issue, this research is conducted to examine how to use social media as marketing tools that in line with Sharia principles, what is the main concern, and what ethics to pay attention to. Ultimately, business players can adopt this concept to reach their targeted customers without fear of disobeying Islamic principles and values.

\section{Islamic Marketing Concept}

In practice, Islamic marketing follows the traditional marketing concept. In the marketing concept, the company as a player who aims to capture value from the customer must go through multiple phases to achieve that goal. Marketing in Islamic refers to the identification and implementation of value maximization strategies for the benefit of the stakeholders and society as a whole based on Quranic and Sunna guidelines (Ahamedullah, 2015). Moreover, discussing the goal of marketing, one of them is the establishment of the customer relationship. The first step is a company needs to understand the marketplace, customer needs, and wants. This is significant in terms of dealing with consumer desires and wishes, and it relates to questions such as "what type of products and services are provided?" and "who will need the goods and services?" Companies must address questions like "about whom the products and services are offered?" and "how to bring the goods and services into the market?" in order to fully comprehend the market. The next 
move is to create a customer-centric marketing approach. Companies who participate in this phase are attempting to evaluate their market segmentation, market strategy, and what differs them apart from their competitors (differentiation and positioning). After completed designing a customerdriven marketing strategy, the next step is to construct an integrated marketing campaign that provides superior value to its customers. This method entails determining the type of marketing campaign, tools, program, and media that a business can use to advertise goods and services to customers in order to raise brand awareness, recognition, and good value for its target market.

Furthermore, companies aim to figure out the marketing mix, which is consists of 4P: price, product, promotion, and place (distribution channel). The fourth step is building profitable partnerships and delighting customers. The business develops customer relationship management and good partnerships with marketing partners through this mechanism. Eventually, the method of capturing money from consumers takes place, resulting in profits and customer equity (Kotler \& Amstrong, 2015). However, when Islam as a religion enters the business world, it necessitates that the whole construct is based on the Islamic model or said to be sharia-compliant. Through the concept of Halal in conventional marketing practice, it becomes a moderating role that internalizes within $4 p$ framework as an aspect of considering Islamic values (Evans, 2010).

\section{Social Media in Islamic Marketing}

Nowadays, social media has emerged as an internet-based platform in multiple forms that connect one person to another. This platform allows everyone to create content, exchange or even share it in a public space that is visible to read and watch. Through social media platforms, both individual and business entity organize their interactions with wider society to get attention, create personal branding or brand awareness, and implement the marketing strategy (Fadahunsi \& Kargwell, 2015). Social media platforms offer several features for organizations and individuals to target their specific audience for marketing purposes. In addition, they can easily maintain interaction and communication with customers to maximize their satisfaction using products and services. For those reasons, business players tend to use social media as marketing gear to enhance business endeavors, yields, and opportunities (Thaker et al., 2020).

A bulk of research works are found on the utilization of social media as a marketing tool. As we can see, some scholar has outlined the basic pattern of engaging social media as part of marketing strategy (Chesbrough, 2006; Bernhoff and Li, 2008; Prahaland and Krishnan, 2008; Deighton and Kornfeld, 2009). The trend of research is then continued regarding the application of social media as an integral element of $21^{\text {st }}$-century business which help them to engage with the customer, build brand trust, and affect their purchase decision (Evans, 2010; Saravankumar et al., 2012; Constantinides, 2014; and Felix et al., 2017). Constantinides (2014) proposed two social media marketing strategies, namely active and passive approaches. In a passive approach, social media is used as the domain for the business player to capture customer experience and customer's voice, whilst the active approach is focusing on the utilization of social media as a marketing tool to perform an e-word of mouth, personalization, direct marketing or even an effective PR. This framework then extended and breakdown into several marketing strategy actions that consist of ten subcategories namely public relation, promotion process, influencer, personalization, cocreator program, participating promotion, engaging with competitors, customer support, social media mix, and marketing intelligence (Ananda et al., 2014). Generally speaking, this attempt has been done to construct a framework from one element of the marketing mix, promotion. Meanwhile, in the Islamic marketing concept, all of the elements involved in marketing practice should be considered in line with sharia principles. This means that not even a single element that exist in the marketing mix does not comply with Sharia. Social media is only tools that utilized by 
business entity or individual to perform their marketing strategy. The most important thing is the content and several things related to the product, service, pricing strategy, and promotion must be free from the forbidden element and unethical behavior based on Sharia guidelines.

Research on Islamic marketing mix in social media practice is still limited. Not many scholars attempt to link and discuss the phenomenon. Fadahunsi \& Kargwell (2015) on their research explain that social media should be included as an integral part of the marketing mix that ultimately facilitates ongoing two-way communication between the organization and mass media (Pantano et al., 2019). Unwittingly, social media reshape the way of people or customers think about the brand and experiences related to certain products and services. Business entity as far as possible avoids negative publicity spread out to the public regarding marketing attributes, bad customer experiences related to products and services, or several activities that lead to damage to the brand in social media platforms.

Based on the literature review above, we find there is a gap between the Islamic marketing mix and the utilization of social media as a marketing tool. Due to the limitations of the study about this topic, the attempt was initiated to study what Islamic values and principles should be applied in the marketing mix contained in the social network campaigns. Besides, the main purpose of this study is to examine the Islamic values in the marketing mix that should be adopted by business organizations or individuals in their effort to utilize social media platforms as marketing tools. Hopefully, this study will be a guideline for internet marketers that targeting Muslim audiences.

\section{Research Method}

This study employs a qualitative as a methodological approach. This method of analysis data used content analysis. The aim was to build a model to describe the phenomenon in a conceptual form (Hsieh et al., 2005). This enables the reduction of phenomena or events into defined categories to better analyze and interpret from this study (Harwood et al., 2003). The goal of this study is to interpret meaning content from text data. In a directed approach, analysis begins with a theory or relevant research findings as basic theory (Hsieh et al., 2005).

This content analysis used a deductive analysis. Deductive content analysis is used when the structure of the analysis is operationalized based on previous knowledge. The deductive approach is useful if the general aim was to test a previous theory in a different situation or to compare categories at different periods. This method is used to determine how Islamic values are implemented in social media marketing strategies. A qualitative method with textual analysis seems to be right to address the research question above, as well as, to completely know what distinguishes traditional marketing from Islamic marketing on social media.

Furthermore, data is collected from written documents such as books, papers, blogs, web material, and internet sources as a basis of information for the marketing model. To analyze contemporary marketing practice, primary sources from Holy Qur'an and hadith are needed to assess whether features and concepts that exist in conventional marketing are currently in line with Sharia principles? If not, what is the Islamic view on it, and what must be applied to achieve the objective of Sharia in the application of Islamic marketing on the social media platform. However, the scope of this research is limited to the discussion of Islamic marketing campaigns on social media with way more focus on the four "P" elements in the marketing mix namely price, promotion, place, and product. 


\section{Results and Discussions}

Islamic marketing can be described in a variety of ways, including marketing to Islamic markets and marketing from Islamic markets. Many components in the Islamic marketing philosophy must be considered by an organization or enterprise that wants to create a marketing strategy that targets the Muslim society as a client, and they are:

\section{Islamic vs Non-Islamic Market}

Islamic markets are concerned with Muslim communities in different parts of the world, including Muslim countries and non-muslim countries with Muslim populations. The term Halal is the most important element that must be used in selling products and services to Muslim communities in the Islamic market. The term halal refers to a company's products and services that are entirely sharia-compliant. However, where halal is overused or not adequately supervised by a sharia law body, such as a sharia council, it may lead to mismatches.

According to Alserhan (2011), There are three kinds of Islamic markets. The first is the largest Islamic market, which means that the bulk of customers are Muslims who purchase Halal products and services. The second is secondary Islamic markets, which have emerged in countries with Muslim minorities. It means that the number of halal products and service providers who deliver halal products to Muslim communities is restricted. The third is the emerging Islamic market. This market consists of Islamic products sold in the non-muslim country, which are purchased not only by Muslims but also by people of other faiths. An example of this market is a bank that provides Islamic financial services in a non-muslim country such as the British Islamic Bank in the United Kingdom, where the majority of their customers are Christians.

Other religions than Islam are the target buyers of non-Islamic markets. The term "nonIslamic economy" was used to describe areas where the bulk of the population is not Muslim, as well as non-muslim populations in Islamic countries. Non-Islamic market societies have consuming patterns that are often similar to Islamic market communities, except that they use halal products in the same way that Muslim communities do.

\section{The Islamic Product and Islamic Company}

The Islamic product means that the goods and service are provided must be halal which follow sharia law and does not consist of elements prohibited by Islam such as usury (riba), gambling (maysir), uncertainty or speculation (gharar), alcohol, pork, an immoral place that invites lust, and many others. These products are prohibited in Islam because it is contrary to the purpose of sharia (maqashid as-syar'i). The Islamic product definition encompasses not just the goods and services made, but also the inputs, processes, and outputs, as well as how they are distributed.

Islamic companies are similar to Islamic products in that they must adhere to sharia provisions in all aspects of their operations, management, human resources, marketing, and, finally, in supplying goods and services that are needed by Muslim communities. Islamic companies differ in three types, they are Islamic companies by product, location, ownership, and customer (Alserhan, 2011). An Islamic company by product try to specialize distribution or production of products that comply with Sharia. This company can come from anywhere in various countries without having to be owned by Muslims. This business will be based in any country and is not required to be owned by Muslims. The firm usually sells to all kinds of Islamic markets, including main, secondary, and emerging markets. For instance, multinational brands such as Nestle and Unilever provide Islamic products to Muslim minorities and the majority in countries 
all over the world. The second form is an Islamic company by location, which means that the company was established, constructed, discovered, and formed in Muslim countries, regardless of whether its owners are Muslim or non-Muslim.

Petronas, Malaysia's national oil corporation, Zam-Zam Cola from Iran, and Aljazeera, Qatar's broadcaster television, are all examples of Islamic businesses from Islamic countries. The third form is an Islamic corporation with Muslim shareholders. The last form is a customer-owned Islamic business, which is similar to the first in that it aims to provide products and services that are tailored to the needs of Muslim societies. This company, which is based in several parts of the world, was established as a traditional business that manufactures certain goods that are permissible under Islamic law. However, the organization continues to respond to Muslim needs by being sharia-compliant and halal-certified. Nestle and Unilever are two examples of this kind of organization.

To summarise, the Islamic marketing model can be described as a system that consists of different elements such as Islamic or non-Islamic markets, products that are manufactured, and businesses that manufacture goods and services themselves, where all of these elements obey the laws that apply in Islam, beginning with input, operation, and output, and all of these elements must avoid the items that are forbidden by Islamic sharia. As a result, Islamic marketing will counter existing marketing practices, but the whole activity is dominated by the Islamic religious system.

\section{Islamic Marketing Mix in Social-Media}

The internet's arrival and the advancement of information technologies have ushered in a modern age, the digital era. People in the modern age use technology and the internet to search for information, entertainment, and even to conduct business. As a result of the internet and information technology growth, the social media network has brought in this age. Many people all over the world use social media platforms to connect, exchange facts, photos, and stories, and search for job openings, or to start a marketing campaign. Twitter, Facebook, LINE, Whatsapp, Instagram, and Youtube are the most popular social media platform that used by everyone to express their activity in digital communities.

Many advertisers are beginning to advertise and endorse themselves on social media as a result of the significant potential that can be captured in easy forms at a lower cost than a conventional marketing strategy. As a result, there are several options available today from social media platforms for corporate organizations or businesses who wish to launch a social media marketing initiative to reach their consumer groups and target consumers. Like Facebook, which opens a wide space for marketers to promote their brands to the public through Facebook Ads. Many social networks are doing the same thing to expand the use of social media as a medium for developing a marketing campaign that is more efficient, fast, and responsive to the needs of modern society.

In Islamic marketing, social media is used as a strategic medium for reaching out to Muslim groups all over the world in the modern age. With the number of Muslims accessing the internet, advertisers (Islamic companies or Islamic goods sold by non-Islamic companies) have a greater potential to products and services to Muslim populations. However, before putting it into practice, marketers should take into account all aspects of the marketing mix, and the rest must adhere to Islamic principles. It ensures that when a marketer begins to develop a social media marketing strategy, they must ensure that all aspects of the Islamic marketing mix are sharia compliant and following Islamic values. 


\section{Products in Halalan Tayyibat's Shell}

Products is defined as a good and service that offered by companies to segment or target market in order to fulfill their needs, wants and yields enough profit to justify its continued existence and has core supplementary and added value on it (Lovelock, 2011; Alserhan, 2011). Products are something that can be offered to the market to get attention to buy, used, or consumed so that it can fulfill wants and needs (Kasmir, 2006). The product consists of product diversity, quality, design, characteristic, brand, packaging, size, etc (Ahmadi \& Hermawan, 2013). In traditional marketing, a product is classified into the level of tangibility such as tangible product is classified as the good, and the intangible product is classified as service. From an Islamic perspective, the goods and services can be called Tayyibat that are follow Islamic provisions or sharia-compliant. Tayyibat means purity, beauty, attractiveness, physical and spiritual cleanliness a usually used along with the word Rizq (sustenance) (Alserhan, 2011).

So eat of the sustenance which Allah has provided for you, lawful and good; and be grateful for the favours of Allah, if it is He Whom ye serve. (Al-Nahl 16:114)

O ye who believe! Eat of the good things that We have provided for you, and be grateful to Allah, if it is Him ye worship. (Al-Baqarah 2:172)

Product in Islamic perspective must prioritize to the value of halal, quality, usefulness, and relevance to human needs and life. In Halal concept, it is not enough to produce the products that are free from prohibited elements under shariah rules, but also essential to provide tayyibat, which implies that the way products are processed, collected, and distributed must be fine, right, and following the sharia provisions. Products that are forbidden in Islam is specifically categorized as haram, the opposite of halal concept. The following items and services are banned in Islam:

a. Services that entice desire, such as prostitution service, spa service with different sexes, etc

b. Slaughtered animals without referencing the name of Almighty Allah S.W.T and dead animals that have not been properly slaughtered.

c. Any intoxicating substance, such as alcoholic beverages, drugs, or something that causes a hangover.

d. Gold and silverware.

e. Silk and gold products for men.

f. Casino and gambling services, including the service that provides speculation and uncertainty.

g. Earning an interest (riba) on lending money.

To summarise, all of the commercial activities in the Islamic perspective must be cleared and free from these categories. Creation, selling, use, and distribution are all activities listed previously. Thus, in order to develop a marketing campaign or program through social media platform, marketers must consider these factors and ensure all of their commercial activities are free of the elements mentioned above that are forbidden by Islamic law (Ishak \& Abdullah, 2012). 


\section{Principle of Justice in Pricing Strategy}

Price defines as the amount of money charged to get a good and service. Kotler \& Armstrong (2011) define price as,

"The amount of money charged for a product or service and the sum of the values that customers exchange for the benefits of having or using the products or service"

The price is an element of the marketing mix that being flexible in the following time, because the price represents a production cost and other elements are involved within. Pricing strategy in companies point of view has different objectives, it can represent the level quality of products, showing the positioning and differentiation of brands, and also represent a whole strategy to compete the others in the market. Price could be an indicator of companies to generate revenue and prosper. In a customer perspective, price refers to the value or benefit they receive in return for the amount they pay and the goods they receive. There is a definition of fairness here between seller and buyer, which means that the price determined by the seller must be honest in terms of the obtained profit from the bought commodity at the paying price, as defined by consumer preferences.

In an Islamic context, pricing must be based on the concept of justice, where the price reflects of the quality offered by the seller or company. If the advertised price is higher but does not reflect the cost of the product that has been paid for or, conversely, if the offered price is lower but does not reflect the quality of the product that has been paid for, then uncertainty or gharar has been added. Gharar, or uncertainty, is a behavior that refers to harming other parties in trading or sale. This activity is prohibited by Islamic law because:

And do not consume one another's wealth unjustly or send it (in bribery) to the rulers in order that (they might aid) you (to) consume a portion of the wealth of the people in sin, while you know (it is unlawful) (Al-Baqarah 2:188)

And also Rasulullah S.A.W:

The prophet Rasulullah S.A.W forbade the sale and purchase of al-hasnah and gharar (H.H. Muslim) ${ }^{1}$

The wisdom of the prohibition of gharar is to prevent losses received by other parties and to anticipate conflicts or hostilities among of buyers and sellers. Companies, on the other hand, have diverse goals when it comes to developing pricing strategies. Some goals are to achieve high-profit margins, reach the break-even point, maximize sales, grow market share, and avoid, reduce, or even exclude competitors. In an Islamic view, price policy objectives could be banned if their nature has the aim of destroying market competition or attempting to take over all consumers in the market through monopolistic pricing practices. This activity and goal are forbidden in the Islamic faith since they will hurt everyone and concentrate as much money as possible on one party. Islam forbids Monopolistic action can be defined as Al-ihtikar, it is a despotic behavior. Allah S.W.T said:

O ye who believe! Eat not up your property among yourselves in vanities: But let there be amongst you Traffic and trade by mutual good-will: Nor kill (or destroy) yourselves: for verily Allah hath been to you Most Merciful! (An-Nisaa' 4:27)

\footnotetext{
${ }^{1}$ HR Muslim, Kitab Al-Buyu, Bab : Buthlaan Bai Al-Hashah wal Bai Alladzi Fihi Gharar, 1513
} 
Rasulullah S.A.W also said:

Narrated from Ahmad bin Nadlor Al-'Askariy, told from Sulaiman Al-Khobairy, told from Baqiyyah bin Walid, told from Tsaur bin Yazid, from Kholid bin Ma'dan, from Mu'adz bin Jabal said: I asked Rasulullah SAW about ihtikar, what is that?Rasulullah SAW said: "when someone (the merchant) hears the cheap price he feels anxious, and when he hears the expensive price, he feels happy, as bad as a servant is a person who does ihtikar, when Allah gives a cheap price he feels troubled, and when Allah giving a high price, he feels happy". (H.H. At-Thobaroniy) ${ }^{2}$

When an organization tries to develop a pricing policy in order to regulate the price in the market by forcing vendors to pay a price that is equal to other comparable goods, the control is Halal. The crucial thing to remember here is that comparative goods contain not just the final price but also all activities involved in creating the price, such as country origin, logistics, and quality (Alserhan, 2011). Price control in Islamic perspective is an action of monopolistic, but it is allowed if the objectives are aimed to avoid injustice among of society, between poorest and wealthiest, that become a right-doing to do such as controlling price in primarily need such as rice, bread, and other basic sustenance products.

Islamic marketers can use the pricing strategy to get good income without having to defeat other marketers, by maintaining the balance of product prices on the market, not doing the practices that cause uncertainty or gharar, being honest in providing prices that are in line with quality, and not doing price monopolies that cause chaos or harm any parties on market. Through using social media as an open-source medium and connecting all people through the internet, an Islamic marketer may offer a product's detailed price, which is then equivalent to its quality. Therefore, they can monitor the price in the market with open source in any platform on the internet to put the right price of the product and what prices are worth being offered to the target market. With a good pricing strategy, sharia-compliant products, and good media, hopefully, will bring God's love and mardhatillah.

\section{Promotion}

Promotion is a type of communication from marketers which informs, persuades, and reminds prospective buyers to influence their opinion or get a response (Lamb et al., 2012). Promotion is often described as an attempt to convey the benefits of a product and convince potential buyers to purchase (Kotler \& Armstrong, 2011). In the word of promotion, three words consist within namely communication, information, and persuasion. Communication is described as the verbal, nonverbal, or written exchange of information between senders and recipients. Meanwhile, the information is the core of something that delivers in communication which contains a collection of data and facts delivered by senders to recipients. The next term is persuasion, which means the marketer try to invite and influence the prospective customer to buy and contact with their product. Marketers use these word components in the promotion to design integrated marketing communication to introduce their target market of customers aware about the brand and product offered, liking them, making them as preference in market, convinced, and finally choosing their brand and purchasing their product (Kotler \& Keller, 2012).

In the Islamic perspective, promotion is described as a written or verbal commitment made by advertisers to prospective customers, as well as the availability of products and services that must be filled out honestly, consistently, and correctly. In Islam, a pledge is a duty that must be fulfilled by the promiser, as broken promises are a symbol of hypocritical behavior that causes

\footnotetext{
${ }^{2}$ Sulaiman bin Ahmad bin Ayyub Abu Al-Qosim At-Thobarony, Al-Mu'jam Al-kabir Juz 15, p. 5
} 
mistrust between parties. It is also a sign of deception or lying, which is contrary to Muslim conduct. In the Holy Qur'an, Allah S.W.T says:

Fulfil the Covenant of Allah when ye have entered into it, and break not your oaths after ye have confirmed them; indeed ye have made Allah your surety; for Allah knoweth all that ye do. (AnNahl: 91)

Come not nigh to the orphan's property except to improve it, until he attains the age of full strength; and fulfil (every) engagement, for (every) engagement will be enquired into (on the Day of Reckoning). (Al-Israa' 17:34)

And also Rasulullah S.A.W. said:

Abu Huraira reported: The Messenger of Allah, peace and blessings be upon him, said, "The signs of a hypocrite are three, even if he fasts and prays and claims to be a Muslim: when he speaks he lies, when he gives a promise he breaks it, and when he is trusted he is treacherous." (H.H. Bukhari) ${ }^{3}$

A marketer must therefore be transparent about the goods being sold when it comes to contact. It means that nothing can be hidden from the customer's view; everything should be straightforward and open. In addition, there are invitation words in terms of marketing that persuade prospective consumers to purchase and use goods. The invitation or persuasion word in Islamic principle is an action to persuade and invite other people to do the right and the good thing from the God's order and leaves the prohibition of God in order to achieve syara' objectives (Almaqashidu Assyar'i). In Islamic commerce, manifestation occurs when products and services do not consist of elements that are forbidden in Islam, are not self and environmentally destructive, and do not persuade people to engage in excessive conduct (israf), greedy (thama'), and redundant behavior (tabzir). Allah S.W.T said:

O Children of Adam! wear your beautiful apparel at every time and place of prayer: eat and drink: But waste not by excess, for Allah loveth not the wasters.

(Al-A'raaf 7:29)

26. And render to the kindred their due rights, as (also) to those in want, and to the wayfarer: But squander not (your wealth) in the manner of a spendthrift.

27. Verily spendthrifts are brothers of the Evil Ones; and the Evil One is to his Lord (himself) ungrateful. (Al-Israa': 26-27)

In sum, the promotion in islamic marketing will follow the following rules (Hassan et al., 2008; Abdullah et al., 2015):

a. Avoidance of sales promotion that use deception.

b. Rejection high-pressure manipulations or misleading sales tactics.

c. Avoidance of promoting product which is categorized as Haram, or contain elements that are prohibited from islamic religion. Intoxicating products, pork, sexual content, etc.

d. Avoidance the persuation strategy that tends to excessive, greedy, and redudant behavior. It is switched with good and right persuation in line with sharia provision.

e. The promotion program and campaign must be open and transparent. Nothing is covered from products in order to get benefit from other parties with wrongdoing way.

\footnotetext{
${ }_{3}^{3}$ Abu abdillah Muhammad ibn Ismail Al-Bukhari, Shahih Al-Bukhari, (Beirut: Dar ibn Al-katsir ed.1, 2002), Kitab Al-iman chapter 'Alamatul Al-Munafiq, No. 33, juz 1, p. 16
} 
f. Avoidance of using appeals as sexual and emotional that inviting lust, immorality, and destructive behavior.

g. Avoidance is something that could be a conflict or controversy in communities such as religious based-issue, the color of skin, conforming background, provocation tone, or use certain ethics in adverting and promotion.

h. Avoidance of using pornographic, nudity, indulgence, and racist content.

All of the above elements must be removed when creating or implementing an Islamic promotion plan and strategy for use in various marketing channels, including social media sites, which are the most powerful marketing media available today that can be distributed broadly and rapidly.

\section{Distribution Channel (Halal Logistic)}

After the existence of products, prices, and promotions, the last but not least element of marketing mix is a place or distribution channel. A distribution channel or place is a company's activities that make products available to the target customer. The distribution channel also called by marketing channel, is the used word for a set of interdependent organizations participating in the process of a making product or service available for use or consumption (Kotler \& Keller, 2012). The most critical aspect of a marketing strategy is the distribution chain, which ensures that goods are manufactured and shipped safely to the intended consumer, allowing the business to gauge customer reaction during consumption. On the other hand, the organization can use a variety of strategies to capture the intended buyer across the intermediaries process, such as the pull and push approach, which is a well-known distribution channel strategy.

Many citizens are almost unaware of the distribution of goods in the context of Islamic trade. Most Muslims are only aware of what is halal and what is haram in terms of goods and services, but they are well-versed in the delivery sense. In the Islamic marketing concept, the distribution channel is regarded as a holistic mechanism that begins with overseeing, regulating, producing, storing, and transporting goods, all of which must adhere to sharia provisions by ensuring that all processes involved are free of forbidden elements. Halalization in the company includes a halal supply chain that spans everything from the procurement and preparation of halal ingredients to the manufacturing and delivery of the final product to the customer (Alserhan, 2011). The halal supply chain has two core that must be understood by marketers before the delivery service goes on, first ensuring that products is free from cross-contamination, means that the company ensures the producing process does not mix with ingredients that are forbidden in shariah law such as blood, animal carcasses, pork-related, alcohol, something intoxicating, or things that can damage the body or environment when consumed.

And cover not Truth with falsehood, nor conceal the Truth when you know (what it is). (AlBaqarah 2:42)

Secondly, by giving assurance to the customer to create the perception of halal logistical operations. The company must provide easy access test lab or open operations to the public to see how they process products and keep maintaining it until no potential contamination is present. Next, by preparing records of all activities started from manufacturing, handling, and movement the products. This approach needs to evaluate the process in the future, only if there is something missed. Its include by giving a knowledge concept of halal supply chain to intermediaries channel to ensure all the process delivered purely sharia-compliant until in hand of the customer. 
Eventually, building an enhanced networking infrastructure that assists companies in organizing networks of suppliers (Hassan et al., 2008)

Furthermore, in Islamic marketing channels, if we look at the channel strategy established previously, known as pull and push strategy, marketers are not allowed to exploit intermediaries channels (reseller and retailer) excessively to maximize the rate of purchasing. This action is forbidden to do in Islamic marketing activity (Ahmed, 2015). As a result, a corporation is not permitted to control the supply of a good for profit. Allah S.W.T said:

And do not eat up your property among yourselves for vanities, nor use it as bait for the judges, with the intent that ye may eat up wrongfully and knowingly a little of (other) people's property.

(Al-Baqarah 2:188)

\section{Conclusions}

Traditional marketing is described as a process in which companies attempt to capture customers and provide a value-based relationship to them, starting with an understanding of the marketplace and customer needs and wants, designing a customer-driven marketing strategy, constructing an integrated marketing program, building profitable relationships with Customer Relationship Management (CRM), and finally capturing valuable customers. The increasing of Islamic awareness in all aspects today has aided all parties interested in the industry in implementing Islamic marketing in their business activities. These elements are the symbol of Islamic marketing that distinguishes it from traditional marketing practice. It also becomes an identity among Muslims themselves. The development of information technology and the internet in the digital era has brought significant changes in marketing. Digital marketing has become a massive phenomenon that is used by almost of all business entities. When Islamic marketing participates in technology advancement in order to extend Islamic marketing concepts to Muslim prospective customers, this has been a serious challenge for marketers to deal with. When creating a sharia-compliant social media marketing program, the marketer must ensure that all marketing mix components are free of Islamic sharia-prohibited products.

Firstly, the product (tayyibat), which mean goods and services, are traded in Islamic marketing must have a halal value which do not contain haram elements such as usury (riba), interest, containing services that invite a lust (prostitution), intoxicating products, gambling services (maysir), etc. Secondly, the pricing strategy prioritizes the principle of justice, where the price reflects the quality of product and service. Both the buyer and the seller must be aware of the item's price, nothing is hidden, no speculative action and uncertainty (gharar). The goal of pricing is not for monopolistic action and ruining competitors, but to maintain price stability and compete healthily and fairly. In addition, the marketer must be honest in setting prices. Thirdly, the promotion strategy that are carried out must not be destructive in terms contain words that persuade people to take excessive, redundant, and greedy actions. Avoidance of using deception, promoting haram products, manipulating sales tactics, dishonest and non-transparent, using sexual appeal, sarcastic and racist words in advertising, etc. Finally, the marketer must ensure all of the dimensions of the distribution channel started from monitoring, controlling, producing, storing, and transporting are free from cross-contamination with haram elements (pork-related products, blood, intoxicating products, alcohol, carcass, etc) and providing an assurance toward customer about halal logistical operations. In addition, Islamic marketer is not allowed to exploit marketing channel in order to pursue profit and manipulate the availability of a product for purpose of exploitation. Using any of these principles, marketers are able to develop a marketing campaign on any social media platform by paying close attention to all dimensions of Islamic marketing that 
may or may not be realized to obtain consumer loyalty with honesty, integrity, accountability, and no coercion, eventually bringing God's mercy and blessing.

\section{References}

Abu abdillah Muhammad ibn Ismail Al-Bukhari. (2002). Shahih Al-Bukhari. Dar ibn Al-katsir ed.1, Beirut. Kitab Al-iman chapter 'Alamatul Al-Munafiq. No. 33, juz 1.

Abdullah, J. B., Hamali, J. H., \& Abdullah, F. (2015). Success strategies in the Islamic marketing mix. International Journal of Business and Society, 16(3).

Ahmadi and Hermawan. (2013). E-Business \& E-Commerce. Andi Offset, Yogyakarta.

Ahamedullah, M. (2015). Islamic marketing ethics and its application in Islamic banking industry. Ahmed, S., \& Rahman, M. (2015). The effects of marketing mix on consumer satisfaction: A literature review from Islamic perspective. Turkish Journal of Islamic Economics, 2(1), 1730.

Alserhan, Bakar Ahmad. (2011). The Principles of Islamic Marketing. Gower, England

American Marketing Association. Accessed on Saturday, 09 Oct. 2018, 06.30 PM. https://www.ama.org/AboutAMA/Pages/Definition-of-Marketing.aspx

Ananda, A. S., Hernández-García, Á., \& Lamberti, L. (2014, June). RENL: A framework for social media marketing strategy. In 1st Annual EDIM PhD Conference, Milan, Italy (pp. 11-12).

Bernhoff J., Li C., (2008), Harnessing the Power of the Oh-So-Social Web, MIT Sloan Management Review, vol 49, nr 3, pp 36-42

Constantinides, E. (2014). Foundations of social media marketing. Procedia-Social and behavioral sciences, 148, 40-57.

Chesbrough H., (2006), Open business models: How to thrive in the new innovation landscape, Boston: Harvard Business School Press

Deighton J., Kornfeld L., (2009), Interactivity's unanticipated consequences for marketers and marketing, Journal of Interactive Marketing, vol. 23, pp. 4-10

Evans, D. (2010). Social media marketing: An hour a day. John Wiley \& Sons.

Fadahunsi, A., \& Kargwell, S. (2015). Social media, consumer behavior and marketing strategy: Implications of "Halal" on Islamic marketing operations. Journal of Small Business and Entrepreneurship Development, 3(1), 36-43.

Felix, R., Rauschnabel, P. A., \& Hinsch, C. (2017). Elements of strategic social media marketing: A holistic framework. Journal of Business Research, 70, 118-126.

Furber, Musa. (2017). Muslim Usage of Internet. Tabah Analytic Brief Research No. 16, (Abu dhabi: UAE). www.tabahfoundation.org

Hassan, Abdul, Chachi, Abdelkader and Abdul Latiff, Salma. (2008). Islamic Marketing Ethics and Its Impact on Customer Satisfaction in The Islamic Banking Industry. JKAU, Islamic Econ.

Harwood, G, T., Garry, \& Tony. (2003). An Overview of Content Analysis. The Marketing Review, 3(4), 479-498.

Hsieh, Hsiu-fang, \& Sarah, E. S. (2005). Three Approaches to Qualitative Content Analysis. Qualitative Health Research, 15(9), 1277-1288.

Imam Muslim, Kitab Al-Buyu, Chapter : Buthlaan Bai Al-Hashah wal Bai Alladzi Fihi Gharar, 1513

Ishak, M. S. B. H., \& Abdullah, O. C. (2012). Islamic perspective on marketing mix. International Journal of Business and Management Studies, 4(1), 121-131. 
Kasmir. (2006). Kewirausahaan. PT Raja Grafindo, Jakarta.

Kottler, Philip and Armstrong, Garry. (2012). Principles of Marketing-14th ed. Pearson, New Jersey.

Kottler, Phillip and Keller, Kevin Lane. (2012). Marketing Management 14-Edition. Prentice Hall, New Jersey.

Lamb, Charles W., Hair, Joseph F.,and McDaniel, Carl. (2012). Essential of Marketing. Mason, South-western Cengage Learning.

Lee, M. and Youn, S. (2009). Electronic word of mouth (eWOM): how eWOM platforms influence consumer product judgement. International Journal of Advertising, Vol. 28 No. 3, pp. 473499.

Lovelock, C., Wirtz, J. \& Chew, P. (2011). 2nd Edition. Essentials of Services Marketing. Singapore: Prentice Hall.

Marinov, Marin. (2007). Marketing in The Emerging Markets of Islamic Countries. Palgrave macmillan, New York.

Prahalad C.K, Krishnan M.S., (2008), The new age of innovation: Driving co-created value through Global Networks, McGraw-Hill

Pantano, E., Priporas, C.-V., \& Migliano, G. (2019). Reshaping traditional marketing mix to include social media participation: Evidence from Italian firms. European Business Review, 31(2), 162-178. https://doi.org/10.1108/EBR-08-2017-0152

Saravanakumar, M., \& SuganthaLakshmi, T. (2012). Social media marketing. Life science journal, 9(4), 4444-4451.

Sulaiman bin Ahmad bin Ayyub Abu Al-Qosim At-Thobarony, Al-Mu'jam Al-kabir Juz 15

Temporal, Paul. (2011). Islamic Branding and Marketing: Creating a Global Islamic Business. John Wiley \& Sons, Singapore.

Thaker, H. M. T., Khaliq, A., Mand, A. A., Hussain, H. I., Thaker, M. A. B. M. T., \& Pitchay, A. B. A. (2020). Exploring the drivers of social media marketing in Malaysian Islamic banks. Journal of Islamic Marketing. 